\title{
An Error Correction Model on the Impact of Government Expenditure on Economic Growth in Liberia from 1970 to 2020: Keynesian Economics Visited
}

\author{
Lester Zomatic Tenny \\ Graduate School of Business, University of Liberia, Monrovia, Liberia
}

\section{Email address:}

drltenny@nocal.com.lr, tennyle@ul.edu.lr

\section{To cite this article:}

Lester Zomatic Tenny. An Error Correction Model on the Impact of Government Expenditure on Economic Growth in Liberia from 1970 to 2020: Keynesian Economics Visited. International Journal of Business and Economics Research. Vol. 10, No. 1, 2021, pp. 21-26. doi: $10.11648 /$ j.ijber.20211001.13

Received: December 21, 2020; Accepted: January 4, 2021; Published: January 12, 2021

\begin{abstract}
Liberia is currently experiencing one of its worse economic decline in over a decade. Various explanations are attributable to this decline. The 2014 Ebola Virus disease, the withdrawal of the multinational peace keeping force and the reduction in its primary exports, rubber, timber, etc can all be cited as causes of such decline. To further inflame the anguish of the economy, the 2019 corona virus disease dampened the hopes for further economic repairs. The decline in the global economies weakens the demand for Liberia's primary exports, iron ore and rubber. Given all these shocks, this research investigated the effect of government expenditure on economic growth in Liberia over the last 50 years. The research used vector error correction model to test for long run relationship between the two variables and found that there is a slightly strong long run relationship between government expenditure and growth, but did not find any short run relationship between government spending and growth. This implies that any non- performance of the budget which is the vehicle used to ferry government activities will have an adverse short run implication on the macroeconomy of Liberia. The research used data on government expenditure obtained from the Ministry of Finance and Development planning in Liberia, the World Bank database for economic growth.
\end{abstract}

Keywords: Vector Error Correction Model, Government Expenditure, Economic Growth, Johanssen Cointegration Test

\section{Introduction}

The speedily and unambiguous support for fiscal involvement in most countries has been somewhat of a surprise [12]. This was simply because of the disbelief that the centuries old classical school of thought was perforated during those gloomy days. The apprehension exhibited by these economists at the time towards the cure of this great economic calamity was not due to Keynes' prescriptions of the antidote to the menace of the Great Depression, but rather the innovator of this remedy was not from the academia and therefore his prescriptions were received with great apprehension. After all, the foundation of classical economics, firmly entrenched and established for centuries, came crumbling down right before their very eyes in an unprecedented fashion.

The presence of John Maynard Keynes shifted the pendulum of economic thought in a radical manner that bears the scars even today. Keynes' General Theory that recommended the intervention of the government (fiscal intervention) to address certain economic anguish was the direction that many countries adopted. Fiscal policies were advocated by them and were welcome for decades. However, many economists had withdrawn support in fiscal policy effectiveness in the $70 \mathrm{~s}$ as a result of the empirically doubtful Ricardian Equivalence Hypothesis (REH) [2]. Nonetheless, since after the global financial crisis of the mid 2000s, many economists are reconsidering the effect of fiscal policy in stabilizing their devastated economies.

\section{Literature Examination}

The idea that fiscal policies could be used to manipulate 
macroeconomic activities is attributed to Keynes. Keynes' theories of output and employment during the economic anguish of the 30 s provided explanation and the remedies for the spiraling high unemployment rate in Europe and America, in which unemployment rates exceeded $25 \%$ and the growth rate of real GDP declined [6].

In order to understand how government expenditure impacts economic growth in Liberia over half a century, this paper acknowledges works of similar nature by others in this section.

There are mixed results and disagreements amongst and between economists on the impact of government expenditure on economic growth. The relationship between government expenditure and economic growth has been approved by Keynesians from a theoretical perspective [9]; while the Neo classicals and calssicals economists have opined that there is a negative impact of government expenditure on growth $[10,8]$. Similarly, there are those who argued that there is a threshold level at which government intervention in the economy through spending could have a negative impact up to certain threshold [9].

Echekoba and Amakor using cross sectional model observed that despite the huge investment in defense, general administration, health and other sectors, there still exist huge economic backwardness in Nigeria [14].

From an empirical perspective, the works of Yasin, Attari and Javed as well as Kimaro, Keong, and Sea all provided justification for the positive link between government expenditure and economic growth $[1,7,9,13]$; Barro using growth model to analyse the impact of the government size on growth and savings concluded that the increase in government spending to non-productive services produces lower per capita growth [15]. On the other hand, the works of Hasnul, Usman, Saez Alvarez-Garcia, and Rodriguez, all showed that there is a negative relationship between government spending and economic growth $[4,9]$. This paper therefore adds to the debate by investigating the impact of government spending on economic growth in Liberia and will contribute to existing body of literature on the discourse.

\section{Empirical Analysis}

The unit roots test was conducted on three variables to test for stationarity or non-stationarity in the model amongst the variables. Herranz opined that unit roots are nonstationary autoregressive (AR) or autoregressive moving-average (ARMA) time series processes [5] that has 1 as a valid root of the characteristic polynomial [3]. The results showed that we can reject the null hypothesis that the series has a unit roots on grounds that the Trace-statistic is Greater than the Probability value for all variables in the series at levels.

Table 1. Unit Roots Test Result.

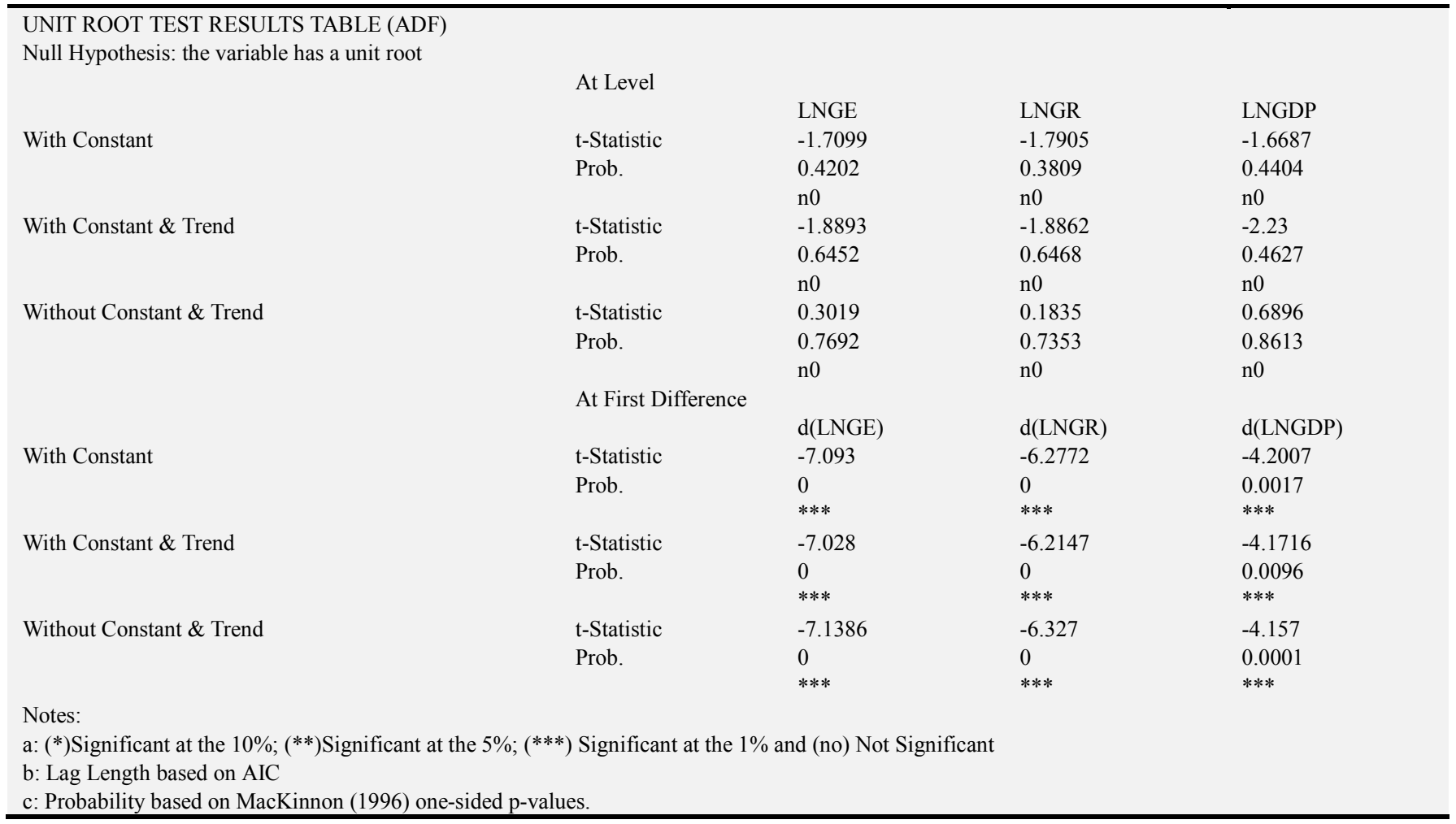

Source: eviews and author computation, 2020

\subsection{Johassen Cointegration Test Results}

Following the test for stationarity or non-stationarity of the variables in the model, using Unit roots test, the next stage in our analysis is to test for long run relationship between the variables. Since the results below in table 2 shows that there is 
cointegrating equation at the $5 \%$ level of significance. The basis for rejection of the null hypothesis at $5 \%$ is that the value for the trace statistic is greater than the value at 5\% (40.18072> 29.79707); the same is applied for the Max-Eigen statistic at
$5 \%$. We can now examine the sigma speed of convergence in the system equation of the error correction model and the alpha coefficient as well as the probability values.

Table 2. Cointegration test results using Johassen method.

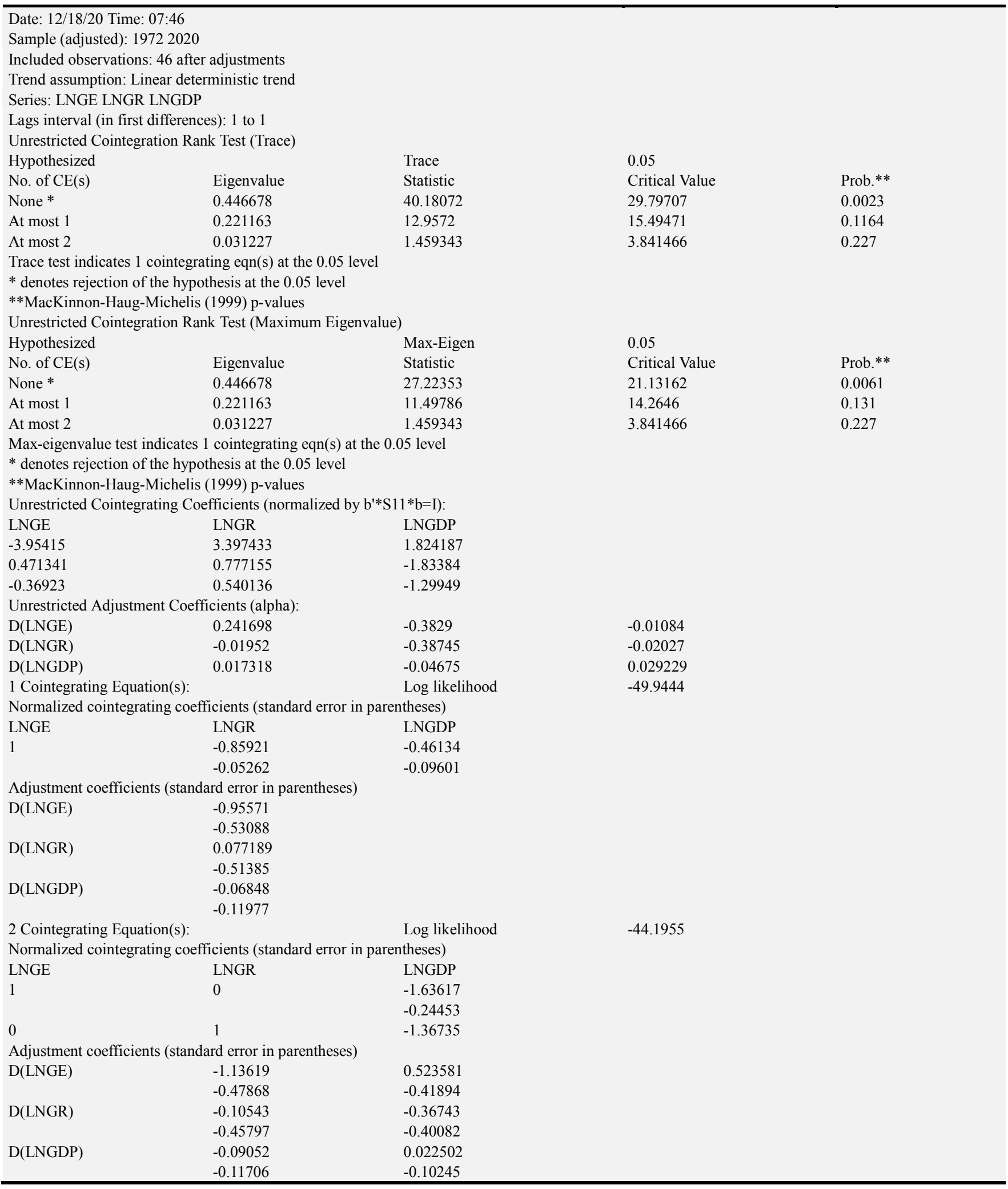




\subsection{Vector Error Correction Model}

The presence of at most 2 cointegrating equations from the Johanssen cointegration test results in table 2 compelled us to now conduct restricted vector autoregression or what we called vector error correction. Table 3 shows the results from the vector error correction model. The model equation for our error correction is given as:

$\Delta \mathrm{LNGE}_{\mathrm{t}}=a_{0}+\sum_{i=1}^{n} \alpha_{\mathrm{i}} \Delta \mathrm{LNGE}_{\mathrm{t}=1}+\sum_{i=1}^{n} \lambda_{\mathrm{i}} \Delta \mathrm{LNGR}_{\mathrm{t}=1}+\sum_{i=1}^{n} \varphi_{\mathrm{i}} \Delta \mathrm{LNGDP}_{\mathrm{t}=1}+\sigma \mathrm{Z}_{\mathrm{t}-1}+\varepsilon_{\mathrm{t}}$

Where LNGE is the log transform of government expenditure; LNGR is the long transformed of government revenue and LNGDP is the log transformed of gross domestic product or economic growth in short.

$Z_{t}$ is the error correction term while $\sigma$ is the speed of adjustment for the variable to converge to the new equilibrium and finally $\varepsilon_{t}$ is the random walk. Some diagnostics tests were conducted on the model to observe stability of the residual and the variables collectively. The first test conducted was the autoserial correlation test followed by White's heteroskedasticity test. There was autoserial correlation in the model which was subsequently removed. We now proceed to interpret the vecm with the probability values from the system equation. The result showed that a $1 \%$ change in government expenditure will give rise to $46 \%$ change in economic growth (GDP). This suggests that there is a slightly strong long run relationship between the growth of government spending (through fiscal implementation) and economic growth in the Liberian economy. This is because the government of Liberia contributes significantly to the overall performance of economic activities, whether it is through employment (the highest employer of labour (human capital comprising of both skilled and unskilled labour) according to the world bank report of 2018); or through purchasing basic logistics such as fuels, stationaries, vehicles, travel, etc.. It can also be said that the government of Liberia annual budget is predominantly recurrent expenditure based. This means that most of the monies collected in the budget go to settle salaries and other consumables in the Liberia economy. The budget as prepared showed very limited portion for investment.

Table 3. Error correction results.

\begin{tabular}{|c|c|c|c|}
\hline \multicolumn{4}{|c|}{ Vector Error Correction Estimates } \\
\hline \multicolumn{4}{|c|}{ Date: $12 / 18 / 20$ Time: $08: 03$} \\
\hline \multicolumn{4}{|c|}{ Sample (adjusted): 19722020} \\
\hline \multicolumn{4}{|c|}{ Included observations: 46 after adjustments } \\
\hline \multicolumn{4}{|c|}{ Standard errors in ( ) \& t-statistics in [ ] } \\
\hline Cointegrating Eq: & CointEq1 & & \\
\hline LNGE(-1) & 1 & & \\
\hline \multirow[t]{3}{*}{$\operatorname{LNGR}(-1)$} & -0.85921 & & \\
\hline & -0.05262 & & \\
\hline & {$[-16.3277]$} & & \\
\hline \multirow[t]{3}{*}{ LNGDP(-1) } & -0.46134 & & \\
\hline & -0.09601 & & \\
\hline & {$[-4.80513]$} & & \\
\hline $\mathrm{C}$ & 6.689541 & & \\
\hline Error Correction: & D(LNGE) & D(LNGR) & $\mathrm{D}$ (LNGDP) \\
\hline \multirow[t]{3}{*}{ CointEq1 } & -0.95571 & 0.077189 & -0.06848 \\
\hline & -0.53088 & -0.51385 & -0.11977 \\
\hline & {$[-1.80024]$} & {$[0.15022]$} & {$[-0.57177]$} \\
\hline \multirow[t]{3}{*}{$\mathrm{D}(\operatorname{LNGE}(-1))$} & 0.423562 & 0.345374 & -0.00355 \\
\hline & -0.40056 & -0.38772 & -0.09037 \\
\hline & [1.05742] & [0.89079] & {$[-0.03925]$} \\
\hline \multirow[t]{3}{*}{ D(LNGR(-1)) } & -0.46516 & -0.3385 & 0.049241 \\
\hline & -0.36062 & -0.34905 & -0.08136 \\
\hline & {$[-1.28989]$} & {$[-0.96975]$} & {$[0.60525]$} \\
\hline \multirow[t]{3}{*}{ D(LNGDP(-1)) } & 0.578926 & 1.025041 & 0.360752 \\
\hline & -0.75772 & -0.73342 & -0.17094 \\
\hline & [0.76404] & [ 1.39761$]$ & [2.11037] \\
\hline \multirow[t]{3}{*}{$\mathrm{C}$} & 0.022387 & -0.02175 & 0.022843 \\
\hline & -0.13684 & -0.13245 & -0.03087 \\
\hline & {$[0.16360]$} & {$[-0.16424]$} & [0.73995] \\
\hline R-squared & 0.132135 & 0.113591 & 0.236323 \\
\hline Adj. R-squared & 0.047465 & 0.027112 & 0.161818 \\
\hline Sum sq. resids & 33.9959 & 31.85053 & 1.730248 \\
\hline S.E. equation & 0.910587 & 0.881386 & 0.205429 \\
\hline F-statistic & 1.560594 & 1.313513 & 3.171907 \\
\hline Log likelihood & -58.3159 & -56.8167 & 10.1775 \\
\hline Akaike AIC & 2.752867 & 2.687681 & -0.22511 \\
\hline Schwarz SC & 2.951632 & 2.886446 & -0.02634 \\
\hline Mean dependent & 0.058279 & 0.031193 & 0.038695 \\
\hline S.D. dependent & 0.932998 & 0.893583 & 0.224385 \\
\hline \multicolumn{2}{|c|}{ Determinant resid covariance (dof adj.) } & 0.002486 & \\
\hline
\end{tabular}




\begin{tabular}{ll}
\hline Determinant resid covariance & 0.001761 \\
Log likelihood & -49.9444 \\
Akaike information criterion & 2.954106 \\
Schwarz criterion & 3.669661 \\
Number of coefficients & 18 \\
\hline
\end{tabular}

Source: author computation in eviews

Table 4. System equation showing probability values.

Dependent Variable: D(LNGE)

Method: Least Squares (Gauss-Newton / Marquardt steps)

Date: 12/18/20 Time: 08:23

Sample (adjusted): 19722020

Included observations: 47 after adjustments

$\mathrm{D}(\mathrm{LNGE})=\mathrm{C}(1) *(\mathrm{LNGE}(-1)-0.859207989694 * \mathrm{LNGR}(-1)-0.46133528999$

*LNGDP(-1) + 6.68954109665 ) + C(2)*D(LNGE(-1)) + C(3)*D(LNGR(

$-1))+\mathrm{C}(4) * \mathrm{D}(\operatorname{LNGDP}(-1))+\mathrm{C}(5)$

$\mathrm{C}(1)$

$\mathrm{C}(2)$

$\mathrm{C}(3)$

$\mathrm{C}(4)$

$\mathrm{C}(5)$

R-squared

Adjusted R-squared

S.E. of regression

Sum squared resid

Log likelihood

F-statistic

Prob(F-statistic)
Std. Error

0.52305

0.394679

0.356123

0.73927

0.134322

Mean dependent var

S.D. dependent var

Akaike info criterion

Schwarz criterion

Hannan-Quinn criter.

Durbin-Watson stat

$\begin{array}{ll}\text { t-Statistic } & \text { Prob. } \\ -1.83839 & 0.0731 \\ 1.084272 & 0.2844 \\ -1.31169 & 0.1967 \\ 0.760008 & 0.4515 \\ 0.149977 & 0.8815 \\ & 0.057313 \\ & 0.922825 \\ & 2.727224 \\ & 2.924048 \\ & 2.80129 \\ & 2.161321\end{array}$

source: author computation in eviews, 2020

The system equation above showed that the speed of adjustment, which is represented by sigma in the model is negative which satisfy the first condition which means economically that there is a long run relationship between government expenditure and economic growth in the Liberian economy. It also means that when there is a departure from long run equilibrium in one period, it will be corrected in the other periods. The next step is to consider whether if there exists a short un relationship between government expenditure and economic growth in the Liberian economy over the period under investigation; that is whether government spending granger causes economic growth. This can be answered from the Wald test where we examine the short run relationship between government spending and economic growth which is shown on the table as c(2) and c(4). The result below showed the Wald test: The result shows that we cannot reject the null hypothesis that government spending does not granger causes economic growth because the result from the chi square probability value is above the $5 \%$ decision criteria. Therefore, we can conclude that there is no short run relationship or causality running from government expenditure to economic growth as shown in table 5 below.

Table 5. Wald test for short run causality.

\begin{tabular}{llll}
\hline Wald Test: & & & \\
Equation: Untitled & Value & df & Probability \\
Test Statistic & 0.094408 & $(2,44)$ & 0.9101 \\
F-statistic & 0.188816 & 2 & 0.9099 \\
Chi-square & & & \\
Null Hypothesis: $C(2)=C(4)=0$ & & -0.03349 & 0.154703 \\
Null Hypothesis Summary: & & -0.06032 & 0.207784 \\
C(2) & & & \\
C(4) & & & \\
Restrictions are linear in coefficients. & & & \\
\hline
\end{tabular}

Source: author's computation in eview, 2020

Once we have obtained the results for the various test, we may want to test for the stability of the model though diagnostics. The null hypothesis is there is no serial correlation in the model. The Breusch-Godfrey Serial Correlation LM test showed that we cannot reject the null hypothesis that there is no serial correlation. There explanation is that the p-value chi square result is above the $5 \%$ decision criteria which is shown on the table as $55 \%$. This result shows that there is no evidence serial correlation. 
Table 6. Breusch-Godfrey serial correlation LM test.

\begin{tabular}{|c|c|c|c|c|}
\hline \multicolumn{5}{|c|}{ Breusch-Godfrey Serial Correlation LM Test: } \\
\hline F-statistic & 0.309661 & Prob. $\mathrm{F}(1$, & & 0.5808 \\
\hline Obs*R-squared & 0.350347 & Prob. Chi- & & 0.5539 \\
\hline \multicolumn{5}{|l|}{ Test Equation: } \\
\hline \multicolumn{5}{|c|}{ Dependent Variable: RESID } \\
\hline \multicolumn{5}{|c|}{ Method: Least Squares } \\
\hline \multicolumn{5}{|c|}{ Date: $12 / 21 / 20$ Time: $11: 00$} \\
\hline \multicolumn{5}{|c|}{ Sample: 19722020} \\
\hline \multicolumn{5}{|c|}{ Included observations: 49} \\
\hline \multicolumn{5}{|c|}{ Presample missing value lagged residuals set to zero. } \\
\hline Variable & Coefficient & Std. Error & t-Statistic & Prob. \\
\hline$C(1)$ & -0.10558 & 0.226704 & -0.4657 & 0.6438 \\
\hline$C(2)$ & -0.39857 & 0.733017 & -0.54374 & 0.5894 \\
\hline $\mathrm{C}(3)$ & -0.13469 & 0.265502 & -0.50732 & 0.6145 \\
\hline $\mathrm{C}(4)$ & -0.01814 & 0.211956 & -0.0856 & 0.9322 \\
\hline$C(5)$ & 0.029216 & 0.068653 & 0.425555 & 0.6726 \\
\hline RESID(-1) & 0.540359 & 0.971044 & 0.556472 & 0.5808 \\
\hline R-squared & 0.00715 & Mean depe & & $-4.64 \mathrm{E}-17$ \\
\hline Adjusted R-squared & -0.1083 & S.D. depen & & 0.283255 \\
\hline S.E. of regression & 0.298198 & Akaike inf & & 0.532163 \\
\hline Sum squared resid & 3.823661 & Schwarz c & & 0.763814 \\
\hline Log likelihood & -7.03799 & Hannan-Q & & 0.620051 \\
\hline F-statistic & 0.061932 & Durbin-W & & 1.978716 \\
\hline Prob(F-statistic) & 0.997267 & & & \\
\hline
\end{tabular}

Source: author's computation in eviews, 2020

\section{Conclusion}

The results from the various test on the effect of government expenditure and economic growth in the Liberian economy over the last 50 years showed that indeed government expenditure does influence economic growth slightly strong in the long run but not in the short run. The implication for such result means that when the budget is not performing as most often the case in Liberia, economic activities may be stagnated in the short run since there exists no short run relationship between both variables. It is only in the long run that we observed that government spending has an impact on growth. This therefore suggests that Keynesian economics which suggests that government spending does influence economic growth is possibly valid for the long run in the Liberian economy and not the short run.

\section{References}

[1] Attari, M. I. J., Javed, A. Y. (2013). Inflation, Economic Growth and Government Expenditure of Pakistan: 1980-2010. Procedia Economics and Finance, 5, 58-67. DOI: 1016/S2212- 5671(13)00010-5.

[2] Barro, R. J. (1989). Economic growth in a cross section of countries. NBER Working Paper, 3120. DOI: 10.1017/CBO9781107415324.004.

[3] Chan, N. H. (2010) Time Series Applications to Finance with $\mathrm{R}$ and S-Plus. Hoboken, NJ: John Wiley \& Sons, Inc.

[4] Hasnul, A. G. (2015). The effects of government expenditure on economic growth: the case of Malaysia. MPRA Paper. Retrieved from: https://mpra.ub.uni-muenchen.de/71254 (25.10.2018).

[5] Herranz, E. (2017) Computational Statistics: Wiley Interdisciplinary Reviews: DOI: 0.1002/wics.1396.
[6] Horton, M. and Germainy, A. (2009) Back to Basics: what is fiscal policy? Access from: http://www.imf.org/external/pubs/ft/fandd/2015/06/basics.htm

[7] Kimaro, E. L., Keong, C. C., Sea, L. L. (2017). Government Expenditure, Efficiency and Economic Growth: A Panel Analysis of Sub-Saharan African Low Income Countries. African Journal of Economic Review, V (II), 34-54.

[8] Lowenberg, A. D. (1990). Neoclassical economics as a theory of politics and institutions. Cato Journal, 9 (3), 619-639

[9] Nyasha, S. \& Odhiambo, N. (2019) The impact of public expenditure on economic growth: A review of international Literature, Folia Oeconomica Stetinensia Volume 19 (2019) Issue 2 DOI: 10.2478/foli-2019-0015

[10] Romer, P. M. (1986). Increasing returns and long-run growth. Journal of Political Economy, 94 (5), 1002-1037. DOI: $10.1086 / 261420$.

[11] Sáez, M. P., Álvarez-García, S., Rodríguez, D. C. (2017). Governmen expenditure and economic growth in the European Union countries: New evidence. Bulletin of Geography. Socioeconomic Series, 36, 127-133. DOI: 10.1515/bog-2017-0020.

[12] Tcherneva, P. R. (2011) Fiscal policy effectiveness: Lessons from the Great Recession. Levy Economics Institute of Bard College. Working paper, 649.

[13] Yasin, M. (2000). Public Spending and Economic Growth: Empirical Investigation of SubSaharan Africa. Southwestern Economic Review, 59-68.

[14] Echekoba, F. N. and Amakor, I. C. (2017) THE IMPACT OF GOVERNMENT EXPENDITURE ON NIGERIA ECONOMIC GROWTH: A FURTHER DISAGGREGATED APPROACH. $N G-$ Journal of Social Development. Vol 6 (3).

[15] Barro, R. (1990): "Government Spending in a Simple Model of Endogenous Growth". Journal of Political Economy, Vol. 98, S103-S107. 